\title{
A study on gender inequality and education
}

Received: 31.07 .2015 ; Accepted: 28.11 .2015

See end of the paper for authors' affiliations

\section{VANDANA VISHWAKARMA}

Department of Home Science

Extension and Communication

Management, College of Home

Science, Maharana Pratap

University of Agriculture and

Technology, UDAIPUR

(RAJASTHAN) INDIA

Email : vandana27.sln@gamil.com
ABSTRACT : Many developing countries including India have displayed gender inequality in education, employment and health. The gender gap in education can be understood in the overall context of the position that women occupy in society. The status of women in India is generally low. They are one of the disadvantaged sections of the society. The disparity between the enrolment of girls and boys has been lessening in the urban areas; the gap between their enrolments is still very wide specially in rural areas. The reasons for this are both economic and social. This study was conducted in Saidpur village of Kurebhar block of Sultanpur district of Uttar Pradesh. For the selection of respondents random sampling was used and percentage was calculated. The objective of this study was to find out the reasons behind gender bias in education. Most of the respondents were not in favor of girl's education due to low socio-economic status and they also thought that girl's education is not necessary.

KEY WORDS: Education, Gender inequality

- HOW TO CITE THIS PAPER : Vishwakarma, Vandana and Bishnoi, Indira (2015). A study on gender inequality and education. Asian J. Home Sci., 10 (2) : 466-470. 